\title{
RECOVERY AND RECYCLING OF ALUMINUM, COPPER, AND PRECIOUS METALS FROM DISMANTLED WEAPON COMPONENTS
}

\author{
J. D. Lutz and W.T. Wheelis \\ Environmentally Conscious Life-Cycle Systems Department \\ Sandia National Laboratories \\ Albuquerque, NM 87185 \\ I. H. Gundiler \\ New Mexico Bureau of Mines and Mineral Resources \\ Socorro, NM 87801
}

\begin{abstract}
Sandia National Laboratories (SNL) is tasked to support the Department of Energy in the dismantlement and disposal of SNL designed weapon components. These components are sealed in a potting compound, and contain heavy metals, explosive, radioactive, and toxic materials in discrete sub-components. SNL developed and demonstrated a process to identify and remove the hazardous sub-components utilizing real-time radiography and abrasive water-jet cutting. The remaining components were then crushed, granulated, screened, and separated into an aluminum and a precious-and-base-metals fraction using air-tables. Plastics were further cleaned for disposal as non-hazardous waste. The New Mexico Bureau of Mines \& Mineral Resources assisted SNL in investigation of size-reduction and separation technologies and in the development of a conceptual design for a mechanical separation system.
\end{abstract}




\section{Acknowledgment}

The authors thank Southwest Research Institute, Magnatech Engineering Inc., Eriez Magnetics Inc., Triple S/ Dynamics, Carpco Inc., Wheelabrator Environmental Systems Inc., SIPI Metals Corp., and United Smelting \& Refining Company for their close cooperation during the course of this study. In addition, the contributions of.William B. Chambers and Michael R. Keenan (SNL, ORG. 1824) on materials characterization and analyses are also gratefully acknowledged. 


\section{DISCLAIMER}

Portions of this document may be illegible in electronic image products. Images are produced from the best available original document. 


\section{Contents}

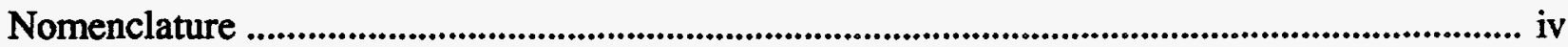

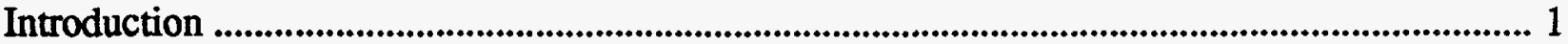

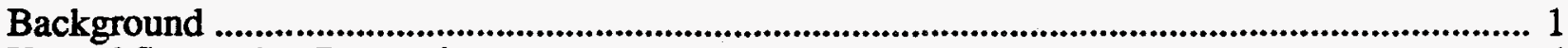

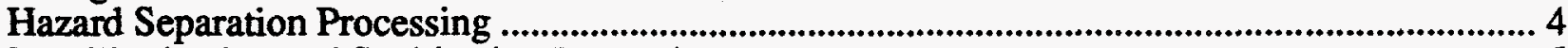

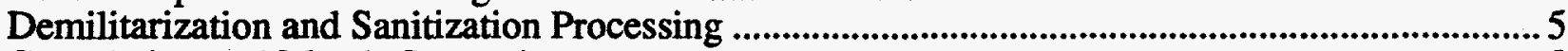

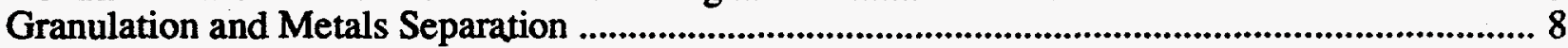

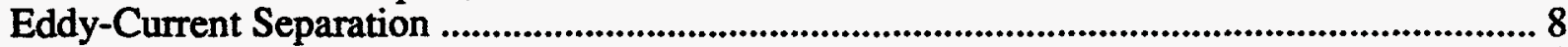

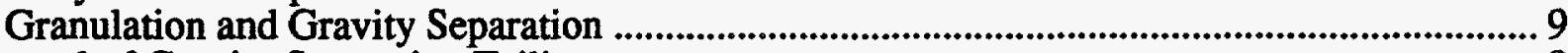

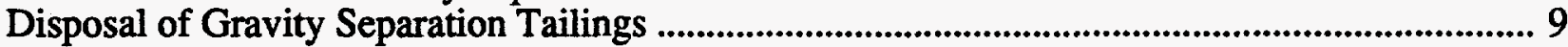

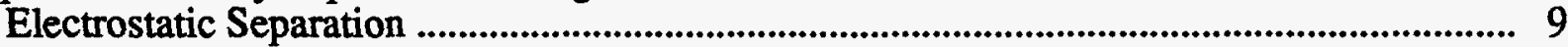

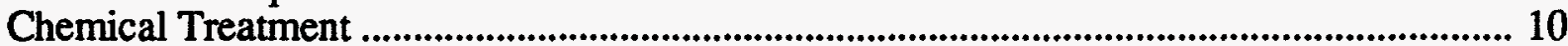

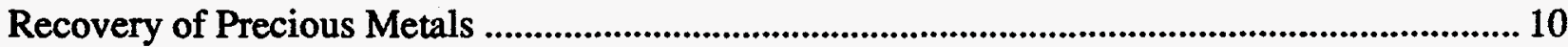

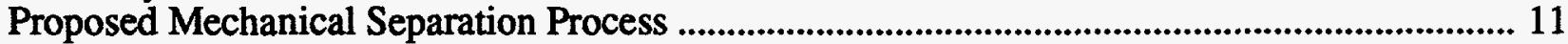

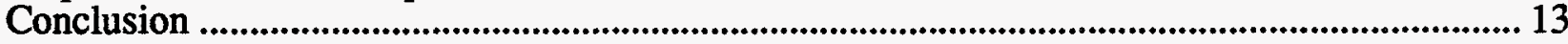

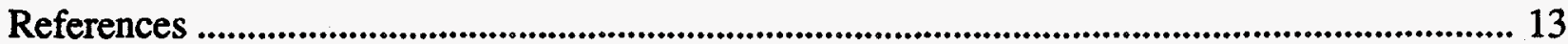

\section{Figures}

1 A B-61 Nuclear Bomb Is Broken Down Into Four Major Sub-Assemblies ........................... 2

2 Arming, Fusing, and Firing Assembly of a Nuclear Weapon ................................................. 3

3 WeDID Process for Nuclear Weapon Components .................................................................. 4

4 Hazard Separation Process Developed Under WeDID Program ....................................... 5

5 A Thermal Battery Removed From a Pre-flight Control Unit ................................................ 6

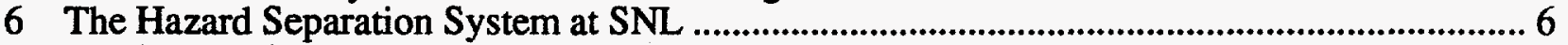

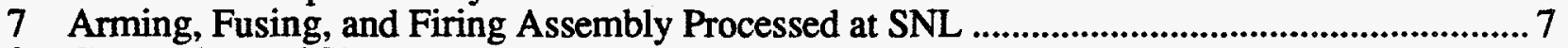

8 Comparison of Shredder and Forge-Hammer Products ........................................................... 8

9 The Proposed Mechanical Separation and Recycling Process ......................................... 12

\section{Tables}

1 SNL Designed Weapon Components .......................................................................................... 2

2 TCLP Results on Gravity Separation Tailings ............................................................................... 10

3 Precious Metal Assays of SNL Material and Separation Products ........................................... 11

4 Equipment Costs for Mechanical Separation Process ..................................................................... 12

5 Estimated Annual Value of Processed Weapon Components .................................................... 13 


\section{Nomenclature}

DOE Department of Energy

EPA

HSS

HTES

OPT

PM

RCRA

SNL

TCLP

TPY Environmental Protection Agency hazard separation system

high tension electrostatic separation troy ounces per metric ton

precious metal

Resource Conservation and Recovery Act

Sandia National Laboratories

toxic characteristic leaching procedure

tons per year

WeDID

Waste Component Recycle, Treatment, and Disposal Integrated Demonstration 


\section{RECOVERY AND RECYCLING OF ALUMINUM, COPPER, AND PRECIOUS METALS FROM DISMANTLED WEAPON COMPONENTS}

\section{Introduction}

Electronic and mechanical components from dismantled nuclear weapons represent a significant waste stream for the Department of Energy. Aside from their ruggedness and the potential presence of hazardous sub-components, the components are very similar to electronic and metal scrap which is processed for metals recovery on a very large scale by $U$. S. Industry.

This report outlines a process for recovering and recycling the metallic constituents of dismantled nuclear weapon components. In addition, the report describes a series of technical demonstrations, conducted at Sandia National Laboratories and within industry, to determine the feasibility and cost-effectiveness of the process.

\section{Background}

During the next decade, many nuclear weapon systems in the U. S. stockpile must be retired and dismantled to comply with arms reduction treaties and force restructuring. Published reports indicate that this reduction will lower the U. S. stockpile from some 25,000 weapons to approximately 6,000 . The weapon systems targeted include artillery rounds, aircraft-delivered bombs, and tactical and strategic missile warheads. The weapon hardware dates from the 1950s through the 1980s and encompasses a wide range of designs and materials.

The Department of Energy (DOE) is responsible for the design, production, stockpile maintenance, and dismantlement of nuclear weapons. The DOE is also responsible for the final disposal of all dismantled nuclear weapon materials. Although weapon dismantlement is not a new activity for the DOE, the increased rate of weapon system retirements coupled with stricter disposal regulations has prompted the DOE to seek improvements in both its dismantlement and disposal processes. ${ }^{1}$ In particular, the DOE has committed to waste minimization and increased material recovery and recycling.

During 1992 - 1993, the DOE tasked Sandia National Laboratories (SNL) to carry out the Waste Component Recycle, Treatment, and Disposal Integrated Demonstration (WeDID). The objective of WeDID was to demonstrate an "end-to-end" process for the dismantlement of SNL designed weapon components. The process was to include the application of innovative technologies for the dismantlement, recycle, treatment, and disposal of weapon components and materials. The process was to emphasize regulatory compliance and material recycling. ${ }^{2}$

SNL is the engineering laboratory responsible for the design of much of the hardware, exclusive of the "physics package," in nuclear weapons. For example, in Figure 1, a B-61 multipurpose nuclear bomb is shown, broken down into its various components. The large metal cylinder is the "physics package" containing radioactive materials. The remaining components are primarily of SNL design and represent a very diverse group of plastic and metal parts. Table 1 lists some of the nuclear weapon components traditionally designed by SNL. These components do not contain special nuclear materials or large amounts of high explosives; however, they may contain hazardous, radioactive, reactive, and toxic materials. Many of the components are potted with an epoxy material to increase their ruggedness. All components are very compact. These attributes make it difficult to separate them into traditional material streams. 


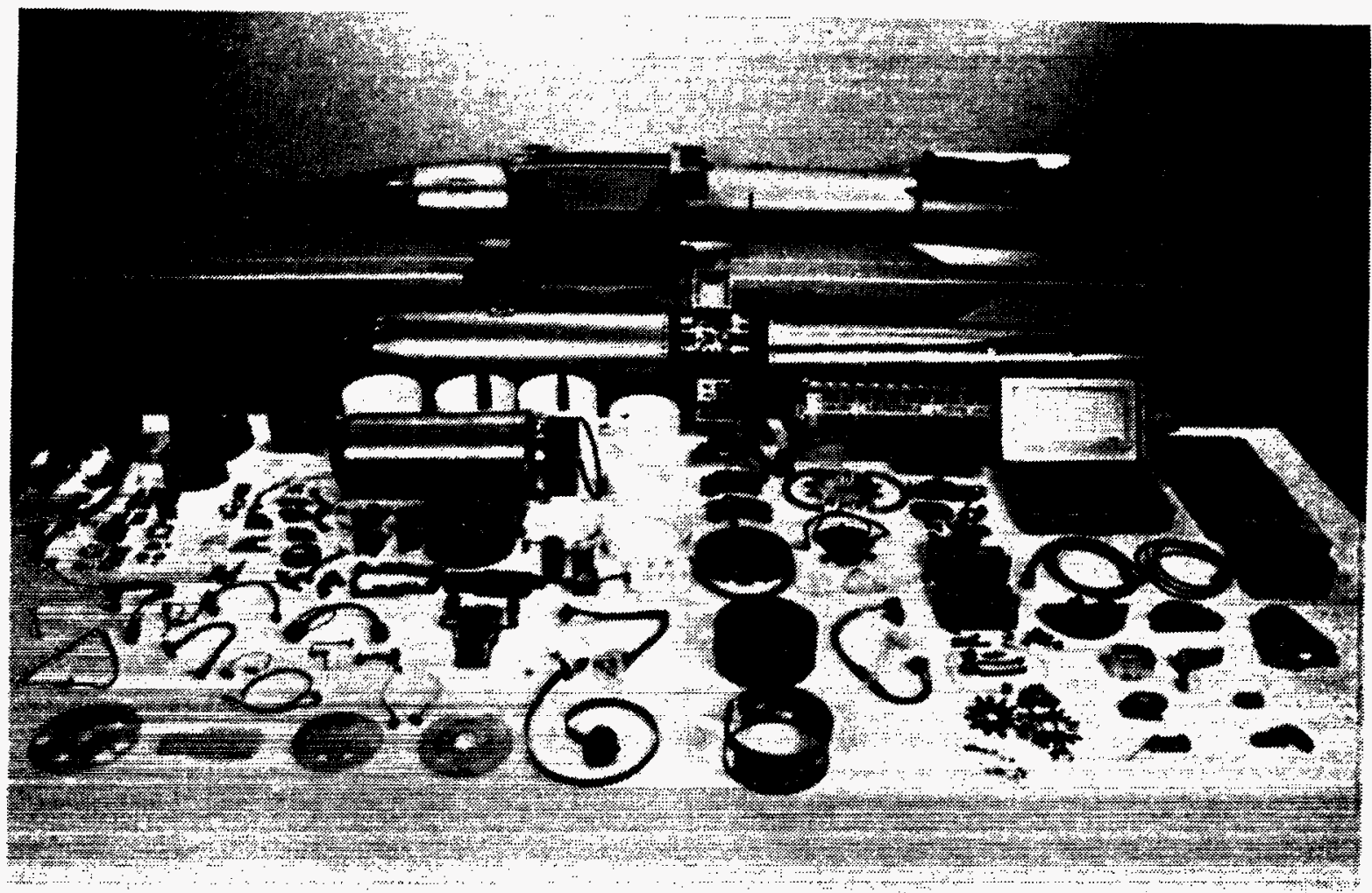

Figure 1. A B-61 nuclear bomb (rear) is broken down into four major sub-assemblies (center), which are dismantled separately (front).

Table 1. SNL Designed Weapon Components

\begin{tabular}{|c|c|}
\hline Catogor & Component \\
\hline Complex Electronics & \begin{tabular}{|l} 
Firesets \\
Radars \\
Programmers
\end{tabular} \\
\hline Electro-Mechanical & $\begin{array}{l}\text { Trajectory Sensing Units } \\
\text { Pre-Flight Controllers }\end{array}$ \\
\hline Passive Electronics & Interconnect Boxes \\
\hline Radioactive & $\begin{array}{l}\text { Neutron Generators } \\
\text { Spark Gaps } \\
\text { Krytons } \\
\end{array}$ \\
\hline Explosive & $\begin{array}{l}\text { Timers } \\
\text { Detonators } \\
\text { Battery Packs } \\
\text { Switch Packs } \\
\end{array}$ \\
\hline Miscellaneous & $\begin{array}{l}\text { Cables/Connectors } \\
\text { Parachutes } \\
\text { Plastics and Foams } \\
\text { Cases and Metal Parts } \\
\text { O-Rings, Seals, and Fasteners } \\
\end{array}$ \\
\hline
\end{tabular}


Of the components listed, the most difficult to process with current methods are the complex electronics and electro-mechanical devices. In Figure 2, an arming, fusing, and firing assembly is shown. A variety of hazardous materials are contained in the assembly including explosives and radioactive materials. These materials are discretely distributed throughout the assembly in smaller sub-components. In addition, the assembly contains a variety of heavy metals, including a significant quantity of precious metals. Estimates indicate that such hardware contains from $\$ 5,000$ to $\$ 15,000$ worth of gold, silver, palladium, and platinum per ton of material.

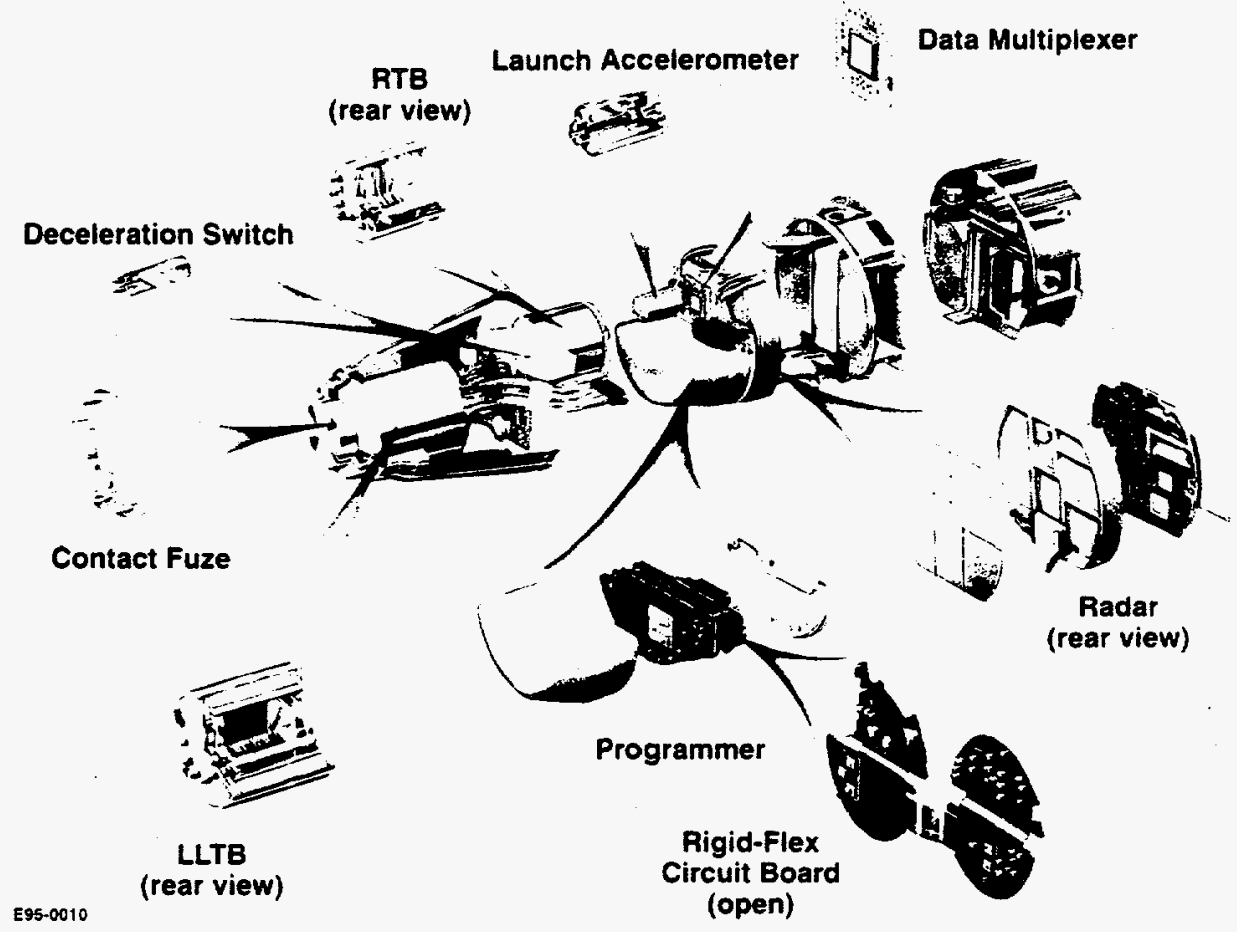

Figure 2. Arming, Fusing, and Firing Assembly of a Nuclear Weapon

In general, the ongoing dismantlement of nuclear weapon hardware represents a material stream totaling some 100 to 300 tons of material per year for 10 to 15 years, exclusive of the "physics package" and the aeroshell. This material stream is roughly $30 \%$ aluminum, $10 \%$ copper, $10 \%$ ferrous, $1 \%$ precious metals, $25 \%$ other metals and inorganics, and $25 \%$ organics.

If separated properly, the majority of material can be recovered through recycling rather than disposed of as hazardous or non-hazardous waste. In addition, the value of the material, in terms of precious metal content, is sufficient to offset the cost of separation processing.

The Sandia National Laboratories proposed and demonstrated an "end-to-end" process which included several major steps. These are: (1) hazard separation, (2) demilitarization/ sanitization, (3) material separation, and (4) recycling and treatment. Figure 3 illustrates the process flow proposed under WeDID. During hazard-separation, weapon components (such as the arming, fusing, and firing assembly) would have the smaller sub-components containing hazardous materials cut-out: These smaller sub-components would then be separated and treated as hazardous waste. The remaining assembly (the bulk of the material) would then be processed for metals recycling and precious metal recovery. During demilitarization and sanitization, all nonhazardous components would be crushed to remove any classification restrictions and to prevent 
further military use. This process would also act to liberate materials sufficiently to allow material separation as a precursor to recycling. Crushed material would then be processed for material separation.

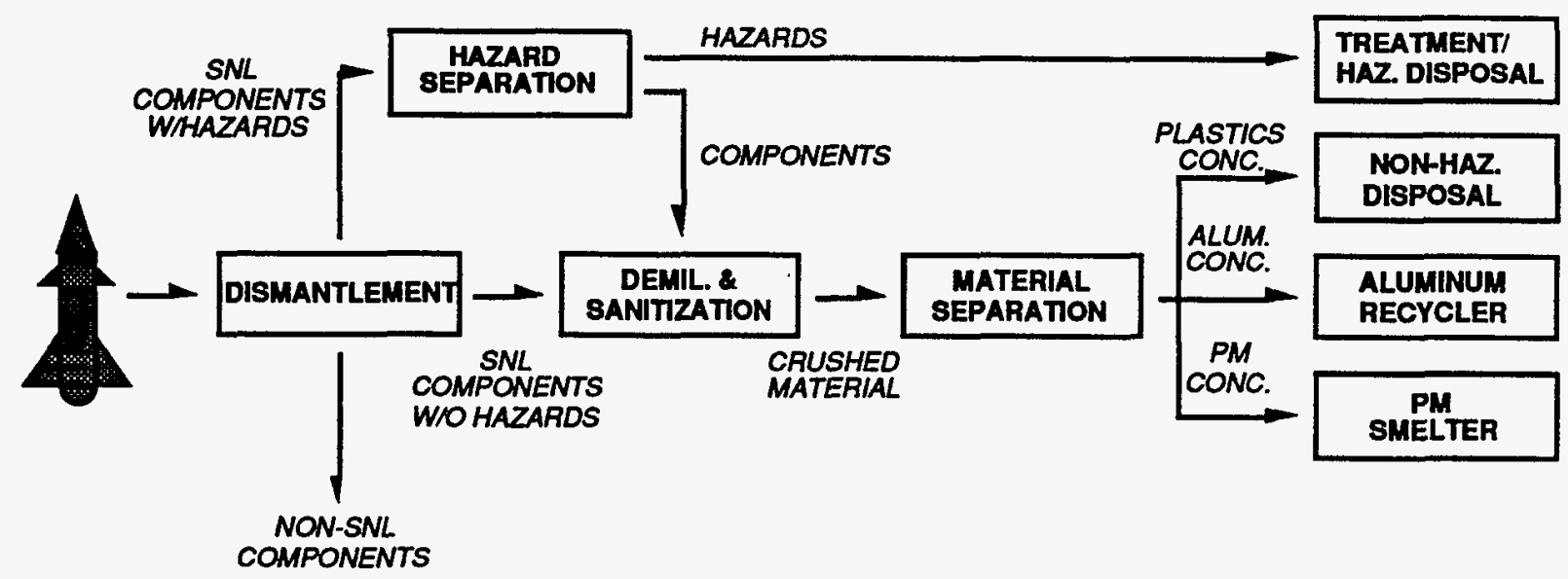

Figure 3. WeDID Process for Nuclear Weapon Components

\section{Hazard Separation Processing}

Hazard separation processing serves an important function, the separation of weapon components into readily disposable waste streams and non-hazardous, recyclable materials. The types of "hazards" requiring removal include: radioactive materials, explosives, reactive metals, oil-filled components, and flammable solids.

These "hazards" are typically in the form of small sub-components located internally to larger electronic or electro-mechanical assemblies. Disposal of many of the hazardous materials listed is regulated by the Resources Conservation and Recovery Act (RCRA).

The Hazard Separation System (HSS) is a system developed at SNL for separating hazardous sub-components from larger weapon components. It is based upon current dismantlement and disposition processes but utilizes more advanced technologies. The two primary technologies are abrasive water-jet technology and real-time radiography. In the system, a Phillips $450 \mathrm{KeV}$ x-ray system is used to produce real-time $x$-ray images on demand for the weapon components to be - processed. The $x$-ray images are input to a computer workstation where they are used to develop or modify cutting tool paths for the abrasive water-jet cutting system. The computer workstation also provides database functions and a software interface through which the operator interacts with the entire HSS. ${ }^{3}$

The abrasive water-jet system itself is a precision cutting system. It produces a focused, high pressure stream of water which is mixed with an abrasive material, making a very effective cutting tool. The tool is mounted on a 3-axis, computer controlled gantry. A programmable controller converts the tool paths generated at the computer workstation into the necessary cutting program and drives the gantry. Multiple components can be processed from the same tool path. Effluents are recovered and filtered, with filtered water reused in the system. Solid materials are captured and analyzed for proper disposal. A process flow diagram developed for processing SNL weapons components is shown in Figure 4. 


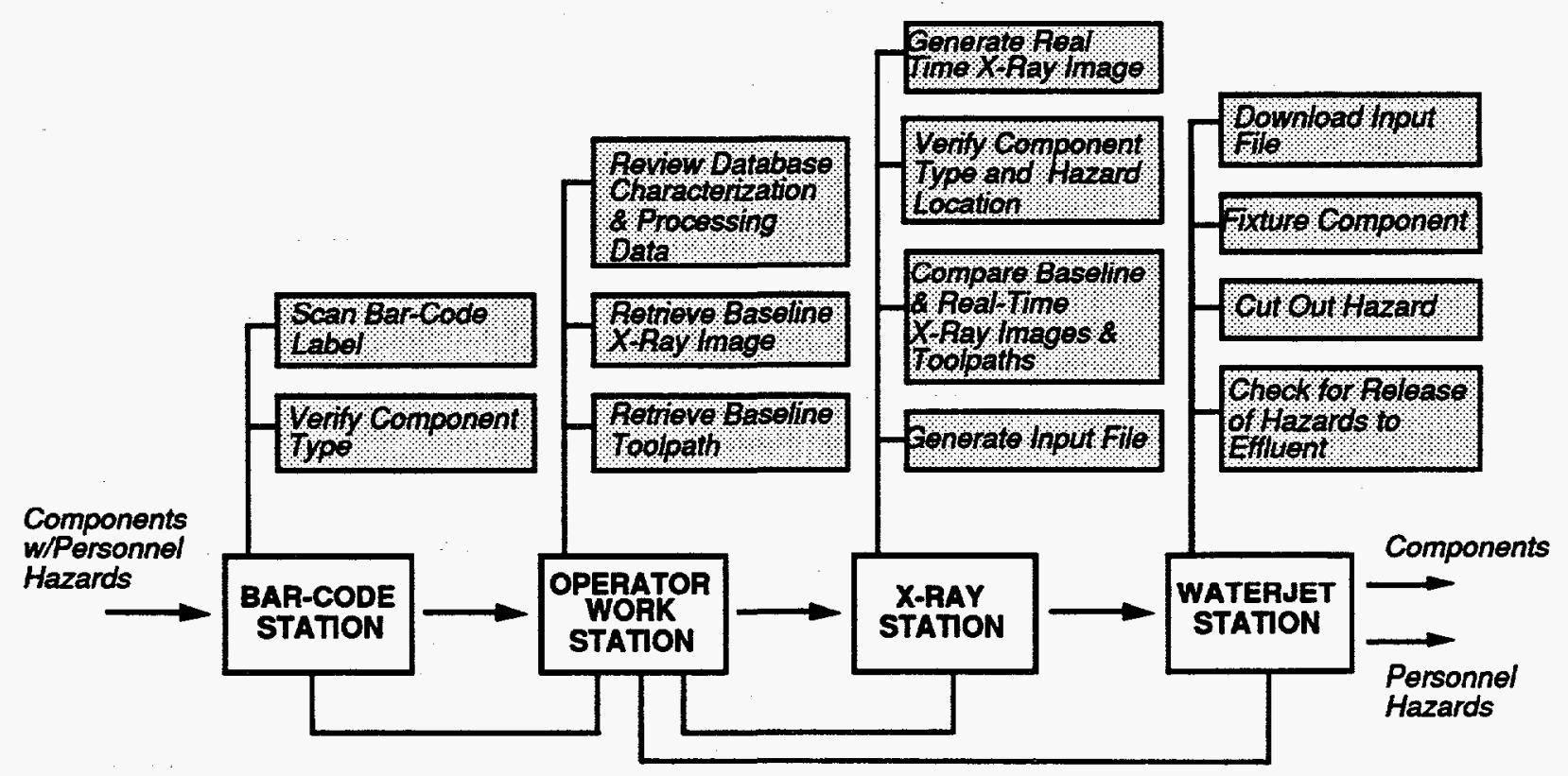

Figure 4. Hazard Separation Process Developed Under the WeDID Program

Initial demonstrations of abrasive water-jet cutting were carried out within industry. In Figure 5 , an abrasive water-jet system was used to remove a thermal battery (foreground) from a preflight control unit. The thermal battery contains both pyrotechnic and reactive materials. The cut required less than two minutes. During 1993, the HSS was assembled at SNL to demonstrate how a fully integrated system would operate. Figure 6 illustrates the HSS facility at SNL. This facility is currently operated as a research and development facility to support the transfer of the technology to main weapon disassembly facilities within the DOE.

A variety of weapon components were processed including the arming, fusing, and firing assembly shown in Figure 7. This assembly was processed to remove a small trigger circuit, internal to the assembly. The trigger contained a small amount of radioactive nickel. Once the trigger circuit was separated, the remaining material was demilitarized and sanitized by crushing and combined with other recyclable materials.

\section{Demilitarization and Sanitization Processing}

Under the WeDID process, demilitarization and sanitization processing occurs after hazard separation and prior to material separation and recycling or treatment. This type of processing is necessary in order to remove the material from the DOE's inventory and release it to industry for recycling and precious metal recovery. The DOE requires that all dismantled weapon components be altered to the extent that they may not be used for their intended purpose. This is called demilitarization. Furthermore, many components (including most complex electronic and electro-mechanical devices) are classified. The DOE requires that all classified traits be totally removed prior to release. This is called sanitization. WeDID has proposed size-reduction techniques as an efficient means for accomplishing both demilitarization and sanitization. In addition, such a process could be used to prepare the material for subsequent material separation processing and/or thermal treatment. 


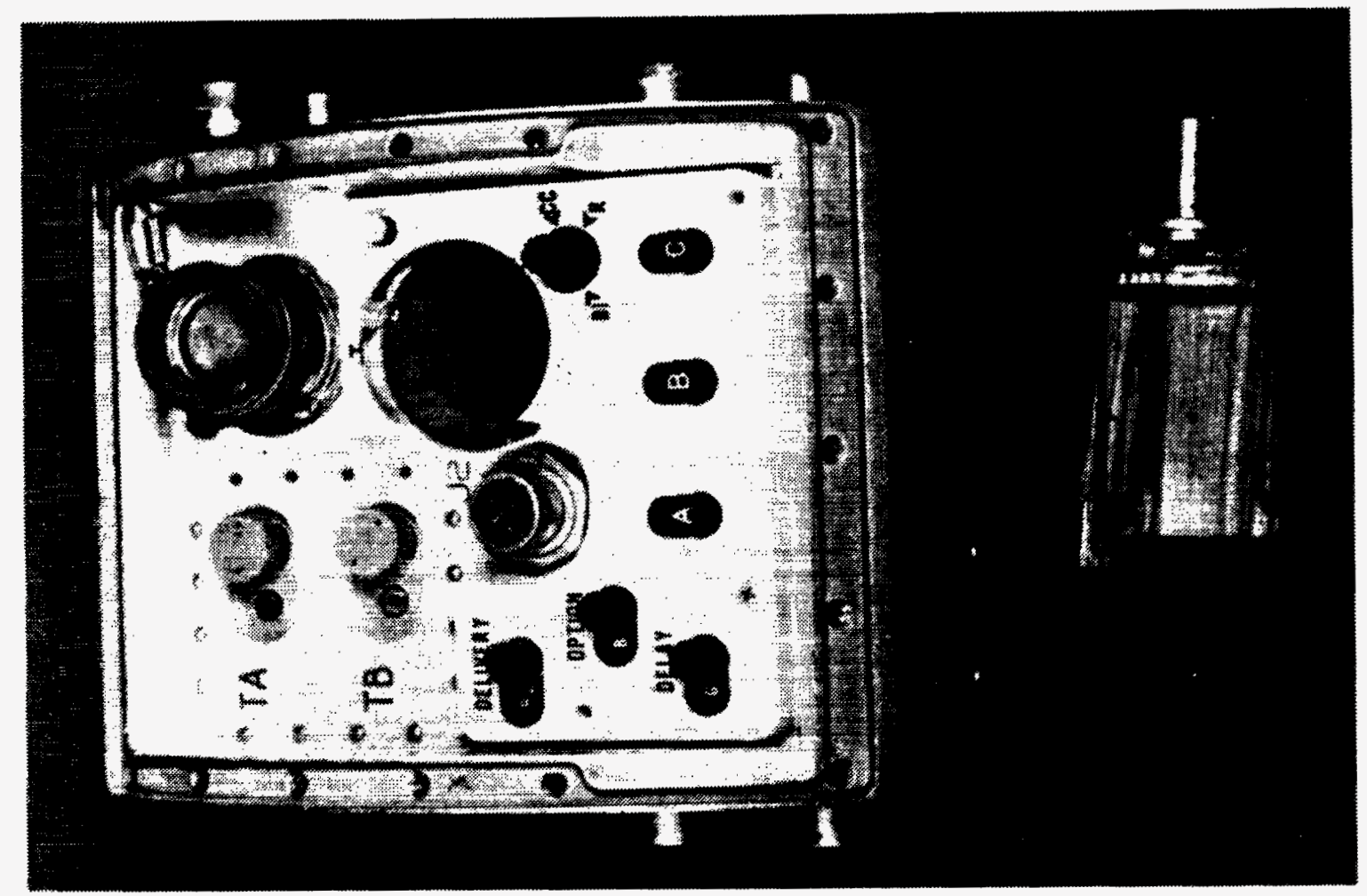

Figure 5. A Thermal Battery Removed From a Pre-Flight Control Unit

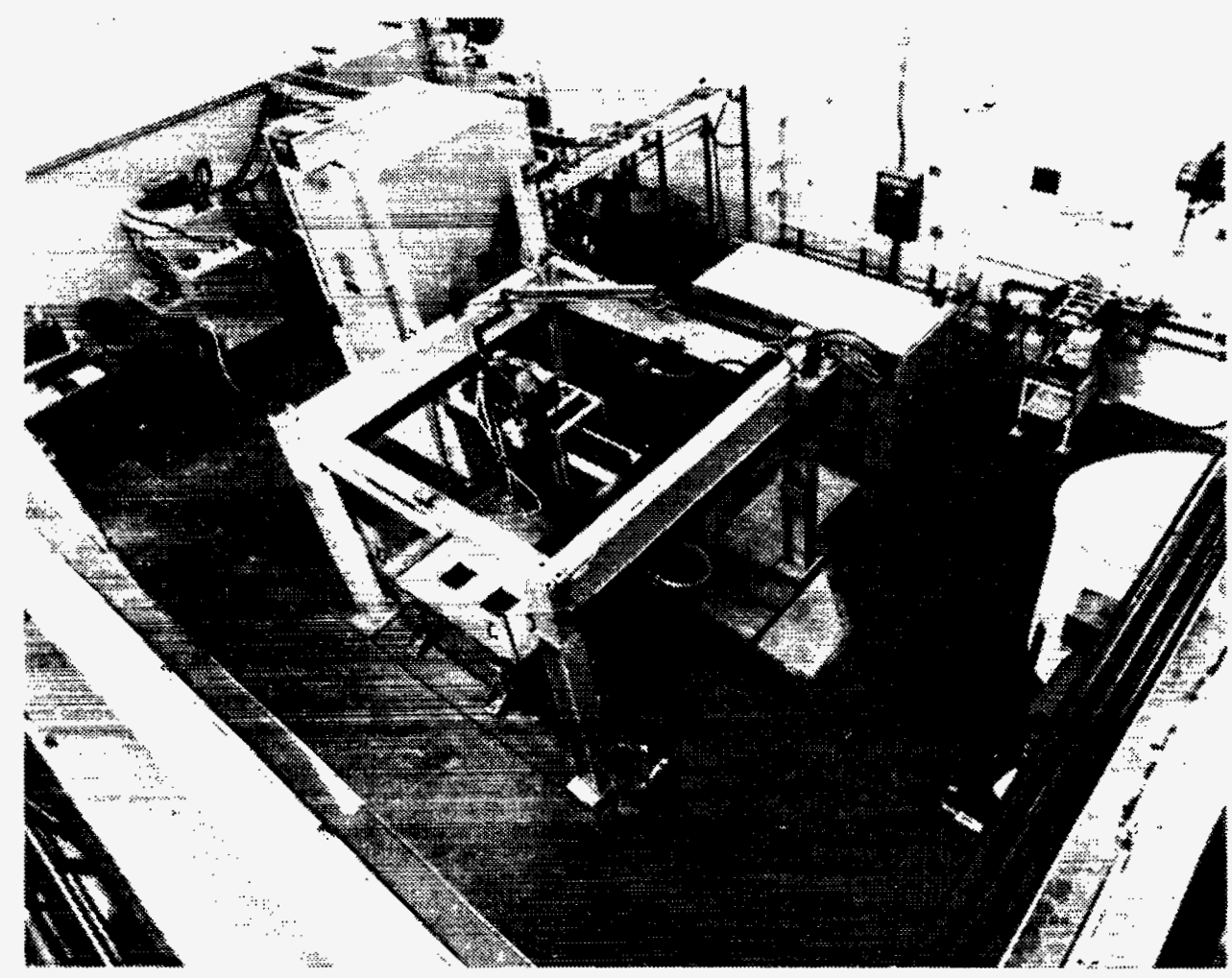

Figure 6. The Hazard Separation System and SNL $\mathrm{X}$-Ray (upper left) and Waterjet (center) 


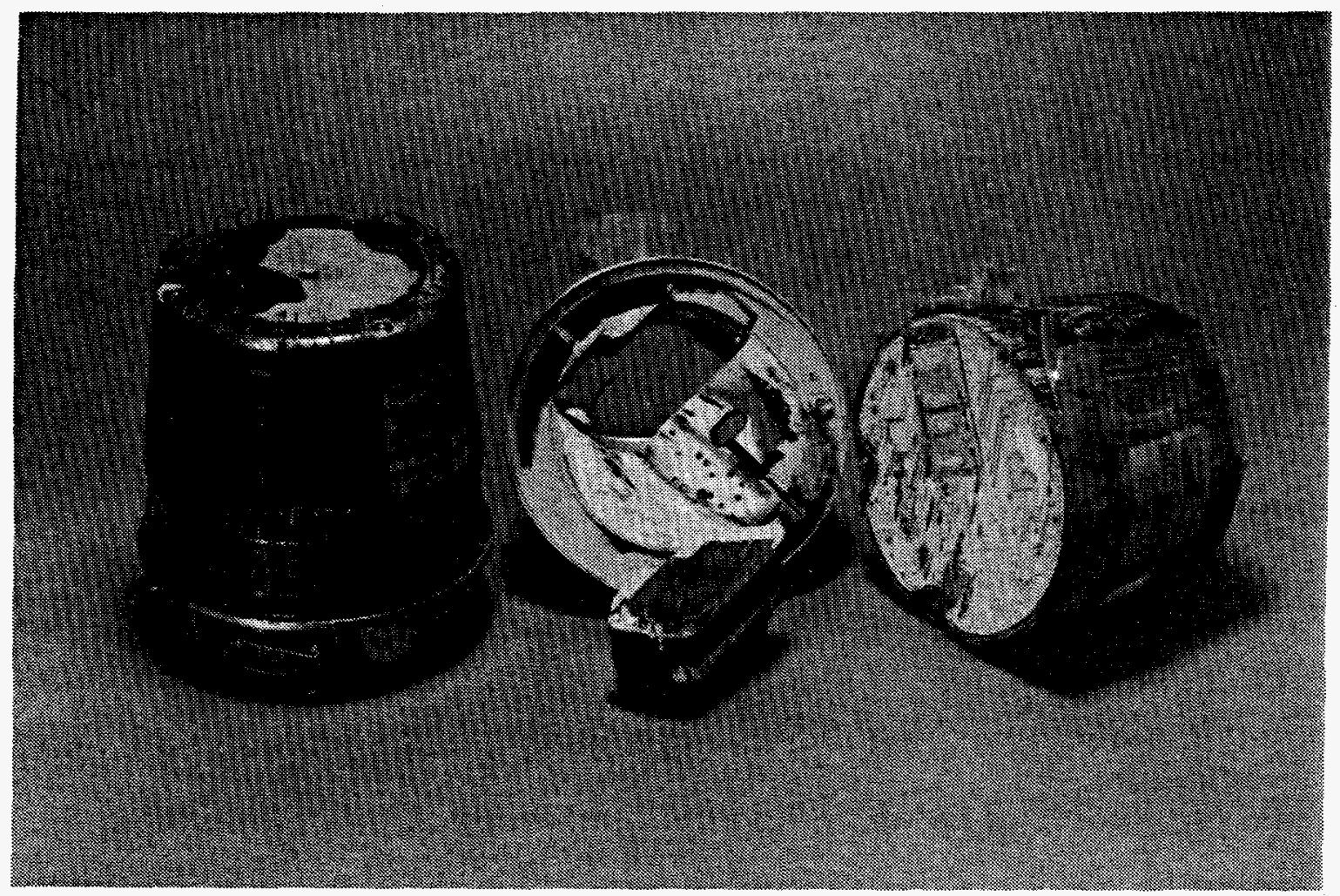

Figure 7. Arming, Fusing, and Firing Assembly Processed at SNL

The size-reduction processes investigated for their applicability to material separation were: (1) cryo-freezing with hydraulic press, (2) shredding, (3) cryo-freezing with forging-hammer, and (4) impact hammer-milling. All processes were demonstrated using real weapon components and materials. Approximately two tons of material were size reduced during the demonstration period. The processes were compared for efficiency, size reduction capability, and material liberation capability.

Cryo-freezing experiments at SNL involved immersing a weapon component in liquid nitrogen. Once "frozen" the components were loaded to failure in a hydraulic press. Although the method adequately provided demilitarization and sanitization, little size-reduction occurred. In addition, the aluminum cases of the weapon components remained ductile, resulting in severe cladding of materials and little liberation.

Cryo-freezing was also investigated using a modified forging hammer as the size-reduction device. 4 Weapon components were "frozen" using liquid nitrogen and then subjected to repeated impacts in the forging hammer. The results indicated that such a process would be very effective for demilitarization and sanitization and would provide significant size-reduction and material liberation. However, some drawbacks to the method were the low through-put and batch-type operational constraints and limited control over size reduction.

Another size-reduction process demonstrated was shredding. SNL experimented with various sized shredders and a number of different types of weapon components. Although the large industrial shredders provided large through-put and continuous operation, the final product was less than satisfactory. The shredders did not adequately sanitize small, classified sub-components and some especially rugged components proved difficult to down-size at all. In addition, cladding occurred frequently and materials were not well liberated. Figure 8 compares shredded material to forge-hammer-crushed material. 


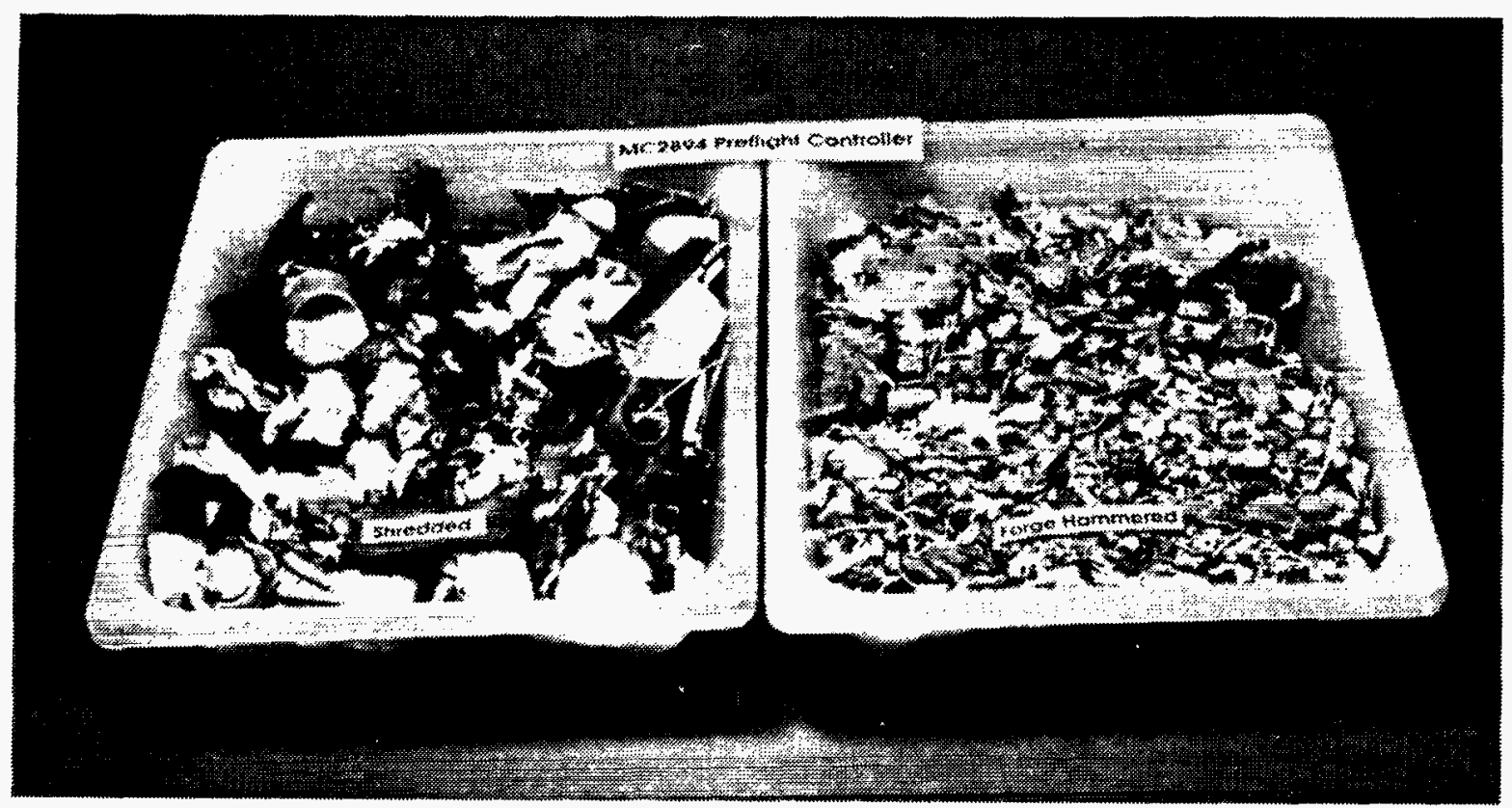

Figure 8. Comparison of Shredder and Forge-Hammer Products Shredded (left) and Forge-Hammered (right)

A final set of size-reduction experiments were conducted with a $60 \mathrm{hp}$ impact mill at Magnatech Engineering Inc. (Tonganoxie, KS). The hammermill contained a set of rotating hammers and could accept continuous material input. Because of its size, several larger weapon components could not be processed; however, the majority of components were processed very effectively. Components were broken up and materials well liberated. By varying screen size, the crusher discharge output material size was adequately controlled.

\section{Granulation and Metals Separation}

Separation of aluminum, copper, and precious metals from plastics was investigated using hammermill-crushed material.5 Screen analysis of this material showed that $58 \%$ was retained on $7 \mathrm{~mm}$ ( $3 \mathrm{mesh})$ and $88 \%$ was retained on $2 \mathrm{~mm}$ (10 mesh) screens. Representative samples of these fractions were used in various separation tests.

\section{Eddy-Current Separation}

Eddy-current separators (ECS) are finding widespread applications in recycling and secondary recovery processes.6,7 Although, the concept of eddy-current separation was developed a century ego, this technology has become affordable and economical to use in recent years with the advent of rare-earth magnets.

ECS tests were conducted at Eriez Magnetics (Erie, PA) with $+7 \mathrm{~mm}$ fraction of hammermill-crushed material. This fraction yielded an aluminum concentrate which analyzed $92 \%$ aluminum, $5 \%$ copper and $2.5 \%$ zinc. It consisted of $22 \mathrm{wt} \%$ of the total crushed material. However, the gold losses to aluminum fraction were considerably high (up to $100 \mathrm{~g} / \mathrm{t}$ ) because of incomplete liberation. The finer size fractions did not yield acceptable separation efficiency. 


\section{Granulation and Gravity Separation}

Gravity separation tests were conducted using Triple-S/Dynamics (Dallas, TX) air-tables. Sutton, Steel, and Steel air-tables (namesake of Triple S/Dynamics) were used extensively for mineral processing at the turn of the century. Presently, they are widely used in agricultural applications and in recycling industries, most notably in the separation of plastic insulation from chopped copper and aluminum cables.

Initial experiments with crushed SNL material did not yield satisfactory separation. The +7 mm fraction was too coarse for this process. The $-7 /+2$ and $-2 \mathrm{~mm}$ fractions included tangles of wires and too many undetached particles. All three fractions were recombined, homogenized, and granulated using Triple S/Dynamics (TS/D) radial-knife type $150 \mathrm{hp}$ granulator. The granulator was equipped with punched-plate type discharge screens with $6.35 \mathrm{~mm}(1 / 4 \mathrm{inch})$ diameter holes. The granulated material was screened through $2 \mathrm{~mm}$ (10 mesh) and $1 \mathrm{~mm}$ (20 mesh) screens, and these fractions were tested on air-tables separately.

The best separation efficiency was obtained with the $+2 \mathrm{~mm}$ fraction, which consisted of $77 \%$ of the granulated material. A heavy metals fraction rich in iron (39\%), copper (30.5\%), and precious metals and an aluminum concentrate analyzing $93 \%$ aluminum and $4 \%$ copper were obtained. Approximately, $90 \%$ of aluminum present in the crushed components was recovered in the aluminum concentrate.

Finer size ( $-2 \mathrm{~mm})$ material mostly consisted of the brittle phases (ceramics) and were poor in organic content. These fractions were also richer in precious metals than the $+2 \mathrm{~mm}$ fraction. Separation efficiency was also low for small particles due to shape effects. Therefore, these fractions were combined with the heavy metals fraction of $+2 \mathrm{~mm}$ air-table products and recycled for copper and precious metals recovery.

\section{Disposal of Gravity Separation Tailings}

The waste fraction of the $+2 \mathrm{~mm}$ air-table separation products consisted mostly of plastics (loss on ignition, 77\%), graphite, ceramics, and less than 3\% metals. Metallic inclusions were mostly aluminum flakes, which were carried into the light fraction, and thin copper wires entrained with the plastics. This fraction accounted for about $23 \mathrm{wt} \%$ of the granulated material.

Preliminary tests using Environmental Protection Agency (EPA) Toxic Characteristic Leaching Procedure (TCLP) indicated that the coarse table tailings met the regulatory limits for all regulated metals (i.e. chromium, mercury, selenium, silver, and zinc) except lead and cadmium. Because disposal of this material to a hazardous-waste depository would be costly (due to its low bulk density and high volume), alternative methods of disposal and other means of rendering this material non-hazardous were investigated.

\section{Electrostatic Separation}

High-tension electrostatic separators (HTES) have recently found widespread application in separation of metallic contaminants from plastics, such as aluminum from recycled food and beverage containers. They are also used to recover metals and clean the plastics from wirechopping operations.

Electrostatic separation tests were conducted at Carpco, Inc. (Jacksonville, FL) using their pilot-plant model HTES. Approximately $7.5 \mathrm{wt} . \%$ of air-table tailings were recovered in the conductor fraction which consisted of mostly graphite, with minor amounts of aluminum and 
copper fragments. The concentrations of these metals in the non-conductor tailings were reduced to $20 \%$ of the original values. Lead and cadmium concentrations were also reduced to 442 and 51 $\mathrm{mg} / \mathrm{kg}$, respectively. Thus, the non-conductor fraction passed the TCLP test for lead but was at the regulatory limit for cadmium. (Further optimization of the HTES operating parameters could yield clean tailings which would meet the regulatory guidelines for disposal as non-hazardous waste).

After HTES treatment, coarse non-conductor tailings can also be considered as fairly high quality fuel. The calorific value of the cleaned tailings was determined as $21 \mathrm{MJ} / \mathrm{kg}(9100$ $\mathrm{Btu} / \mathrm{lb}$ ), which is comparable to sub-bituminous coals used in power plants in Southwestern United States. Possibilities to ship the tailings to coal-fired power plants, or waste-to-energy plants, were also explored.

\section{Chemical Treatment}

The TCLP tests also showed that lead and cadmium can be removed from the tailings by leaching with a dilute acid solution. However, such a process would require separation and disposal of lead and cadmium from the effluents.

Another option to render the air-table tailings non-hazardous for disposal to a landfill is the fixation of lead and cadmium on solids. One of the available technologies, the Wes-Phix process, was originally developed by the Wheelabrator Laboratories (Hampton, $\mathrm{NH}$ ) to immobilize heavy metals in the ash residues from their waste-to-energy power plants. This process is now licensed to other industries by Wheelabrator Environmental Systems, Inc. Fixation tests conducted on gravity separation tailing samples before and after HTES showed that the tailings would pass the TCLP test for both lead and cadmium after the Wes-Phix treatment. These results are tabulated in Table 2.

Table 2. TCLP Results on Gravity Separation Tailings (mg/kg)*

\begin{tabular}{|c|c|c|c|c|}
\hline \multirow[t]{2}{*}{ Matoral } & \multicolumn{2}{|c|}{801018 - Wes.hWL } & S1tor & Mssom \\
\hline & 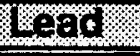 & Oadmum & Uaro & odmum \\
\hline Air-Table Tailings & 14.0 & 1.9 & $<0.5$ & 0.52 \\
\hline HTES Non-Conductors & 4.0 & 1.1 & $<0.5$ & 0.32 \\
\hline
\end{tabular}

${ }^{*}$ Regulatory limits: Lead $=5.0$ and Cadmium $=1.0$.

\section{Recovery of Precious Metals}

Smelting is the most widely used method for recovering precious metals (PM) from printed circuit boards and other electronic scrap. 8,9 There are a number of well established secondary metal smelters in the country. Recovery methods typically include the removal of organic material by thermal decomposition, dissolution of PM-bearing scrap in molten copper, oxidation of impurities to slag, and casting of ingots. Copper ingots are usually shipped to a copper refinery for PM recovery.

Smelting tests were conducted at two secondary smelters, SIPI Metals Corporation (Chicago, IL) and United Smelting \& Refining Company (Franklin, IL). Initial smelting/assay tests were conducted with rubblized (forge-hammer crushed) components. Organics were charred and the roasted cinder was screened through $1 \mathrm{~mm}$ ( $20 \mathrm{mesh})$ screens. The screen undersize was assayed 
with conventional fire assay techniques. The oversize material was melted in copper in a crucible furnace with flux additives. Slag and melt were then sampled and assayed separately. Smeltingassay tests on a sample of granulated material used for separation tests, and on a composite PM concentrate of separation products, were also conducted. The concentrate was produced by combining the $(-2 \mathrm{~mm})$ screen undersize with $(+2 \mathrm{~mm})$ heavy metals fraction of air-table products. Table 3 summarizes these assay results.

\section{Table 3. Precious Metal Assays of SNL Material and Separation Products}

\begin{tabular}{|c|c|c|c|}
\hline 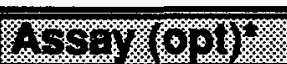 & 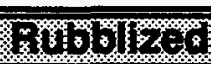 & WHWWHeO & WHPSWRT \\
\hline Gold & 11.67 & $\overline{9.95}$ & 21.3 \\
\hline Silver & 49.46 & 59.77 & 123.5 \\
\hline Palladium & 2.26 & 2.68 & 10.3 \\
\hline Platinum & ND & 1.75 & 2.7 \\
\hline Copper (wt.\%) & 15.2 & NA & 32.3 \\
\hline
\end{tabular}

*Troy ounce per short ton (opt) $=\mathbf{3 4 . 3}$ grams per metric ton. NA: Not-analyzed, ND: None detected.

The assay results for rubblized (forge-hammer-crushed) and granulated (hammermillcrushed) materials reflect the variability of PM content between the lots of weapon components sampled. These results also show that the concentrate is approximately twice as high in PM values. Thus, when $(+2 \mathrm{~mm}$ ) aluminum fraction (mids) and the air-table tailings (plastics) are separated, the material treated at a smelter would be reduced $50 \%$ by weight ( $67 \%$ by volume) and it would be twice as concentrated in PM values (Table 3).

\section{Proposed Mechanical Separation Process}

Results of the separation tests described above indicated a number of benefits from reducing the amount of material to be treated at a smelter through removal of coarse aluminum and plastics. These benefits include recovery and recycling of aluminum, disposal of bulk of the plastics as non-hazardous waste, and reducing the transportation costs and smelting charges.

As part of the study undertaken, a mechanical separation process has been proposed. This process involves granulating and screening the crushed material, and separating the screen oversize $(+2 \mathrm{~mm})$ using a dry (gravity) separation process into a heavy metals, a medium specific gravity (aluminum) fraction, and a light fraction of mostly plastics and ceramics. A conceptual flowsheet for the proposed separation process is given in Figure 9.

The cost of the crushing and separation system can be expected to approach $\$ 700,000$, excluding the building cost and installation. Equipment costs for major hardware items are given in Table 4. Against the capital and operating costs, however, the increase in smelter returns should be considered. Although an accurate sampling and analysis of the weapons components to be recycled has not been completed to date, a conservative estimate of the metal values in these components for the projected volume of 100 tons per year are tabulated in Table 5.

The recycle value of the recovered aluminum $(\$ 5 \mathrm{~K})$ is minimal as compared to the value of precious metals. However, smelting costs will be reduced by $50 \%$ when coarse aluminum and 


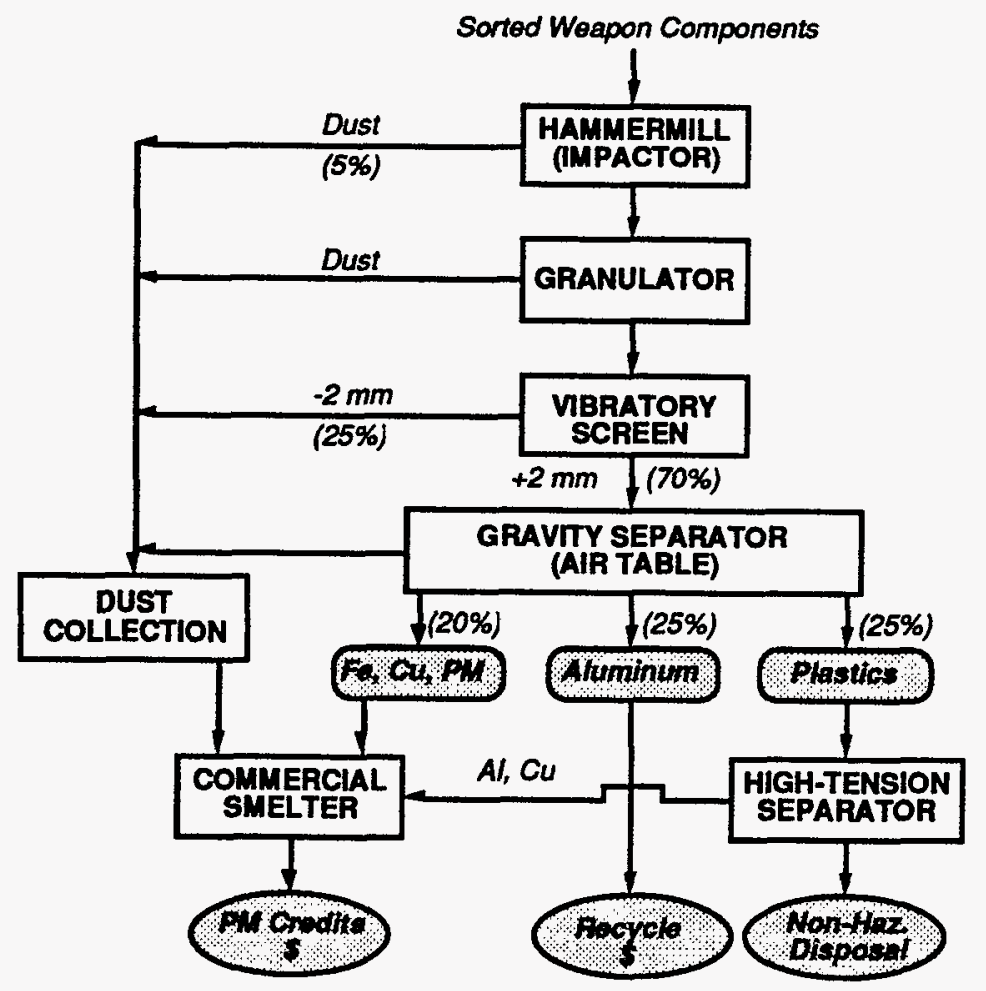

Figure 9. The Proposed Mechanical Separation and Recycling Process

plastics are separated from the material to be treated at the smelter. Furthermore, aluminum is a troublesome diluent for the PM smelters; once it is removed from the smelter feed, a more favorable treatment rate can be negotiated. Savings in the treatment charges would result in higher revenues than can be realized by weight reduction alone. It is estimated that $\$ 200 \mathrm{~K}$ per year can thus be saved by granulating and separating the hammermill-crushed material. This amount would pay for the separation equipment (excluding the crusher and dust collection system) in the first year and annual operating expenses for subsequent years. In addition, recycling aluminum would save energy and demonstrate a commitment to recycling consistent with DOE objectives.

Table 4. Equipment Costs for Mechanical Separation Process

\begin{tabular}{||l|c|}
\hline \multicolumn{1}{|c|}{ Equlpment } & Cost \\
\hline $60 \times 30$ Hammermill & $\$ 200 \mathrm{~K}$ \\
\hline $600 \mathrm{hp}$ Motor & $\$ 25 \mathrm{~K}$ \\
\hline Motor Controls & $\$ 25 \mathrm{~K}$ \\
\hline Fluid Coupling & $\$ 30 \mathrm{~K}$ \\
\hline Granulator & $\$ 65 \mathrm{~K}$ \\
\hline Air Separator & $\$ 25 \mathrm{~K}$ \\
\hline Screen & $\$ 10 \mathrm{~K}$ \\
\hline High Tension Electrostatic Separator & $\$ 100 \mathrm{~K}$ \\
\hline Ancillary Equipment & $\$ 120 \mathrm{~K}$ \\
\hline Dust Collection System & $\$ 100 \mathrm{~K}$ \\
\hline \multicolumn{2}{|c|}{ Total $=$} \\
\hline
\end{tabular}


Table 5. Estimated Annual Value of Processed Weapon Components *

\begin{tabular}{|c|c|c|c|}
\hline Hewas & SW1/STS & Veree & Tolaj \\
\hline Gold & 10 opt & $\$ 350 / 0 z$ & $\$ 350 \mathrm{~K}$ \\
\hline Silver & $50 \mathrm{opt}$ & $\$ 4 / 0 z$ & $\$ 20 \mathrm{~K}$ \\
\hline Palladium & $2.5 \mathrm{opt}$ & $\$ 100 / 0 z$ & $\$ 25 \mathrm{~K}$ \\
\hline Platinum & $1 \mathrm{opt}$ & $\$ 350 / 0 z$ & $\$ 35 \mathrm{~K}$ \\
\hline Copper & $15 w t \%$ & $\$ 0.5 / \mathrm{lb}$ & $\$ 15 \mathrm{~K}$ \\
\hline Aluminum & 25 wt\% & $\$ 0.1 / \mathrm{lb}$ & $\$ 5 \mathrm{~K}$ \\
\hline \multicolumn{4}{|c|}{ Total $=\$ 450 \mathrm{~K}$} \\
\hline
\end{tabular}

*Values based upon 100 TPY in material stream.

\section{Conclusion}

The recovery and recycling of the metal constituents of dismantled weapon components represents an economical and environmentally responsible method for the disposal of these materials. Recovery and recycling can be accomplished effectively using commercially available equipment and smelting services. An efficient process begins with the separation of hazardous sub-components (which is required for proper disposal and waste minimization). Material downsizing techniques can then be used to efficiently render components sanitized and demilitarized while at the same time preparing the material for mechanical separation. Material separation prior to commercial processing for precious metal recovery or aluminum recycling allows for maximum return of value.

\section{References}

${ }^{1}$ K. Cameron, Taking Apart The Bomb, Popular Science, April, pp. 64-69, 102-103, 1993.

2 W.T. Wheelis, Recycle and Treatment Approaches for Weapon Components, in New Mexico Conference for the Environment, held in Santa Fe, NM, 1992, pp. 686-693, Sandia National Laboratories, 1992.

3 J. D. Lutz, et. al., A Hazard Separation System for the Dismantlement of Nuclear Weapon Components, SAND Report in process, Sandia National Laboratories.

4 P. G. Neiswander, Modifications to a Forging Hammer for the Size-Reduction of Weapon Components, SAND94-2430 in process, Sandia National Laboratories.

${ }^{5}$ I. H. Gundiler, Weapon Component Waste Disposal - Separation and Recycling, Final Report for Contract AC-6640, Sandia National Laboratories, 1994.

${ }^{6}$ D.A. Norrgran and J.A. Wernham, Recycling and Secondary Recovery Applications Using an Eddy-Current Separator, Minerals \& Metallurgical Processing, November, pp. 184-187, 1991.

7 J. Borsecnik, Eddy Joins the Work Force, Scrap Processing and Recycling, July/August, pp. 111-116, 1992. 
8 J.E. Hoffman, Recovering Precious Metals from Electronic Scrap, JOM, July, pp. 42-48, 1992.

9 R.J. Garino, Making the Most of Electronic Scrap, Scrap Processing and Recycling, January/ February, pp. 65-71, 1989. 


\section{DISTRIBUTION:}

1 New Mexico Bureau of Mines and Mineral Resources

Attn: I. H. Gundiler

Socorro, NM 87801

2 Mason \& Hanger - Silas Mason Co.

Attn: G. C. Cockrell - Explosives Technology Division

W. Reams - Component Engineering Section

Amarillo, TX 79177

1 MS0342 W. B. Chambers, 1824

10342 M. R. Keenan, 1824

10447 E. W. Graff, 5111

$50730 \quad$ J. D. Lutz, 6625

$10730 \quad$ P. G. Neiswander, 6625

10730 W.T. Wheelis, 6625

19018 Central Technical Files, 8523-2

50899 Technical Library, 13414

10619 Technical Publications, 12613

20100 Document Processing, 7613

For DOE/OSTI 